\title{
Further biological and molecular characterization of actinophage VWB
}

\author{
Jozef Anné, ${ }^{1 *}$ Lieve Van Mellaert, ${ }^{1}$ Benny Decock, ${ }^{2}$ Jo Van Damme, ${ }^{2 \dagger}$ \\ Arthur Van Aerschot, ${ }^{3}$ Piet HerdewiJn ${ }^{3} \dagger$ and Hendrik Eyssen ${ }^{1}$ \\ ${ }^{1}$ Laboratory of Microbiology, ${ }^{2}$ Laboratory of Immunobiology, and ${ }^{3}$ Laboratory of Pharmaceutical Chemistry, \\ Rega Institute, University of Leuven, B-3000 Leuven, Belgium
}

(Received 21 September 1989; revised 13 February 1990; accepted 26 March 1990)

\begin{abstract}
The development cycle of the temperate actinophage VWB was investigated. Adsorption of most phage particles occurred within 30 min and the adsorption constant was $0.6 \times 10^{-8} \mathrm{ml} \mathrm{min}^{-1}$. The latent and rise periods were 140 and $100 \mathrm{~min}$, respectively, and the burst size was estimated to be 130-250 p.f.u. Although phage VWB could infect only Streptomyces venezuelae ETH 14630 (ATCC 40755), of six different $S$. venezuelae strains tested, phage DNA could be introduced by transfection into most non-infectible strains. Upon transfection, phage DNA was propagated in these non-infectible strains and phage particles were released. In addition, the transfected strains could be lysogenized. By comparison of restriction fragments of VWB DNA, either free or integrated in the chromosomal DNA of the $S$. venezuelae ETH 14630 lysogen, the attachment site was localized. PAGE of the phage proteins revealed at least 17 different proteins with three major bands estimated as $16.5,27 \cdot 2$ and $43 \mathrm{kDa}$ in size. The N-terminal amino acid sequence of these supposed major head and tail proteins was determined. The corresponding DNA sequences on the phage genome were localized using oligonucleotides synthesized on the basis of the N-terminal amino acid sequences. The genes coding for the major structural proteins were shown to be clustered, as has been observed for other bacteriophages.
\end{abstract}

\section{Introduction}

Several articles have mentioned the isolation of actinophages infecting Streptomyces strains (e.g. Ackermann et $a l .$, 1985). Most phages have been isolated from soil in which they are widespread, but some isolates were obtained from lysogenic wild-type strains. Among the reasons for the interest in phages are the fact that they can be used as a tool for the genetic analysis of host strains (Stuttard, 1983; Chung \& Thompson, 1985), and that some phages are suitable for the development of a phage-based cloning vector (Chater, 1986). With a few exceptions, however, actinophages have not been studied in much detail. Their characterization has been limited to the description of some morphological properties and the construction of a restriction map.

To obtain a better understanding of actinophage biology and the regulatory processes involved in phage replication, more fundamental studies are required. This knowledge could be useful in the isolation and identi-

$\dagger$ Research Associate of the Belgian Nationaal Fonds voor Wetenschappelijk Onderzoek.

The amino acid sequence data in this paper have been submitted to GenBank and have been assigned the accession numbers A33075, B33075, C33075. fication of interesting regulatory sequences including repressor proteins (Sinclair \& Bibb, 1988) or sequences involved in transduction (McHenney \& Baltz, 1988). It is also of importance to obtain a better insight into phage taxonomy and evolution.

In a previous article we reported the isolation of actinophage VWB (Anné et al., 1984). This temperate phage, with a genome size of $47.3 \mathrm{~kb}$ and cohesive ends (Anné et al., 1985), is infectious to Streptomyces venezuelae ETH 14630. The phage is rather unique in its resistance to chelating agents and it is able to package stably at least $\mathbf{4} \mathrm{kb}$ of additional DNA (Van Mellaert $\boldsymbol{e t}$ al., 1987). Consequently, it is of potential use for development as a phage-based cloning vector. Therefore, we were interested in studying this phage in more detail and we have determined both the characteristics of the development cycle of VWB and the narrow host specificity. Furthermore, the attachment site (att) as well as the start of the three most prominent structural phage proteins were localized on the phage genome.

\section{Methods}

Organisms, phages and plasmids. Streptomyces phage VWB and VW3 (Anné et al., 1984) were propagated on S. venezuelae ETH 14630 
(=ATCC 40755). SV1 (Stuttard, 1983) and SVL1 (see Results) were cultured on $S$. venezuelae ATCC 10595. The host ranges of different actinophages were checked on the following strains: $S$. venezuelae ATCC 10712, ATCC 14583, ATCC 21113 and DSM 40727; and Streptomyces exfoliatus ATCC 12672. Plasmid pBR322 (Bolivar et al., 1977), used to clone restriction fragments of VWB, was propagated in Escherichia coli JM83 [ara $\Delta\left(\right.$ lac proAB) rpsL $\Phi 80$, lacI ${ }^{a} \Delta($ lacZ) M15]. VWB04 is a derivative of VWB. It contains a thiostrepton resistance gene as selection marker and is $48.5 \mathrm{~kb}$ in size (Van Mellaert et al., 1987).

Media and buffers. Streptomyces strains were cultured on R2YE (Hopwood et al., 1985) or ISP-2 medium (Difco). Phage particles were maintained in phage buffer (Anné et al. 1984). Protoplasts were prepared in $\mathrm{P}$ medium (Okanishi et al., 1977) from $S$. venezuelae mycelia grown in $\mathrm{S}$ medium (Hopwood et al., 1985) supplemented with $0.6 \%$ glycine, and they were regenerated on R2YE medium. S medium supplemented with $0.6 \%$ glycine was also the medium to culture Streptomyces for chromosomal DNA isolation. E. coli was cultivated in liquid LB medium (Miller, 1972) and transformants, obtained as described by Maniatis et al. (1982), were selected on solid LB. When applicable, antibiotics were added to the medium at final concentrations of 100 and $50 \mu \mathrm{g} \mathrm{ml}^{-1}$ for ampicillin and thiostrepton, respectively. DNA was stored in TE (0.01 M-Tris/HCl, 0.001 M-EDTA, $\mathrm{pH}$ 7.5). Buffers required for restriction enzyme digestions were obtained from Boehringer Mannheim.

Propagation of $S$. venezuelae phages. All platings for phage assays were carried out by the agar layer technique (Adams, 1959). High-titre lysates $\left(10^{11}\right.$ p.f.u. $\left.\mathrm{ml}^{-1}\right)$ were obtained on solid phage medium and, in the case of VWB, occasionally in liquid phage medium. On solid medium, lysates could be harvested after $20 \mathrm{~h}$ of cultivation, whereas in liquid cultures at least $32 \mathrm{~h}$ of incubation was required. For liquid cultures, mycelial fragments $\left(\mathrm{OD}_{590}=0 \cdot 1\right)$ were infected with phage particles at an m.o.i. between 0.001 and 1.0, depending on the type of experiment, and cultures were incubated on a rotary shaker $\left(27^{\circ} \mathrm{C}, 350\right.$ r.p.m.). Determination of the host range was done on solid phage medium by addition of $50-100 \mu \mathrm{l}$ phage suspension $\left(10^{10}-10^{11}\right.$ p.f.u. $\mathrm{ml}^{-1}$ ) on top of the soft agar medium inoculated with mycelial fragments of the strain to be investigated. Infection could be scored by the presence of plaques in a lawn of Streptomyces mycelium after $20 \mathrm{~h}$ incubation $\left(27^{\circ} \mathrm{C}\right)$.

Purification of phages and denaturation of phage proteins. Phages from high-titre lysates were purified by $\mathrm{CsCl}$ gradient centrifugation as described previously (Anné et al., 1984). Gradients were prepared with $0.785 \mathrm{~g} \mathrm{CsCl} \mathrm{ml}^{-1}$ for VWB and $0.715 \mathrm{~g} \mathrm{CsCl} \mathrm{ml}^{-1}$ for SV1 and other $S$. venezuelae phages. Phage proteins used for immunization or gel electrophoresis were denatured by treatment of $\mathrm{CsCl}$-gradient-banded phage particles with $2.3 \%(\mathrm{w} / \mathrm{v})$ SDS in the presence of $5 \%(\mathrm{v} / \mathrm{v})$ $\beta$-mercaptoethanol at $95^{\circ} \mathrm{C}$ for $3 \mathrm{~min}$. Denatured phages were dialysed $(3 \times 2 \mathrm{~h})$ against $0.01 \mathrm{M}-\mathrm{Tris} / \mathrm{HCl}, \mathrm{pH} 7.5$.

Antiserum production. Serum containing VWB antibodies was prepared in rabbits as described by Adams (1959). The amount of phage antibodies, expressed as $K$, was calculated from the formula $K=2 \cdot 3 D / t \times \log \left(p_{0} / p\right)$, where $p_{0}=$ phage assay at zero time, $p=$ phage assay at time $t$ min and $D=$ final dilution of serum in the phage-serum mixture (Adams, 1959).

Adsorption. Adsorption experiments were carried out with VWB suspensions added to mycelial fragments at an m.o.i. of 0.01 . Suspensions were incubated with gentle shaking at $27^{\circ} \mathrm{C}$. Samples were withdrawn at regular intervals after contact. The mycelial fragments were removed by centrifugation $(5 \mathrm{~min}, 5000 \mathrm{~g})$ and the number of phages remaining in the supernatant was counted as p.f.u. $\mathrm{ml}^{-1}$ on the tester strain. The rate of adsorption was determined as described by Adams (1959).

One-step growth experiment. Mycelial fragments were infected with VWB particles at an m.o.i. of 0.001. Following adsorption for $15 \mathrm{~min}$, the suspension was treated with diluted $(1: 20)$ rabbit antiserum $(K=10)$ for $20 \mathrm{~min}$ at $27^{\circ} \mathrm{C}$ and subsequently diluted 500 -fold before incubation $\left(27^{\circ} \mathrm{C}, 350\right.$ r.p.m. $)$. At regular intervals $1 \mathrm{ml}$ samples were withdrawn, centrifuged $(5 \mathrm{~min}, 5000 \mathrm{~g}$ ) and the number of phage particles in the supernatant estimated as p.f.u. $\mathrm{ml}^{-1}$ on a lawn of $S$. venezuelae. Burst size was calculated according to Adams (1959), the number of infectious centres being estimated from the adsorption efficiency.

Separation of phage proteins by PAGE or by hydroxylapatite chromatography and detection of protein bands. Phage proteins (10 to $100 \mu \mathrm{g}$, depending on the staining method) along with a calibration kit for molecular mass determination (Pharmacia) were subjected to SDSPAGE under reducing conditions in $12.5 \%(\mathrm{w} / \mathrm{v})$ gels $(1 \mathrm{~mm}$ thick) according to Laemmli (1970). After electrophoresis, proteins were either visualized in the gel by staining with Coomassie Blue R-250 (Chrambach et al., 1967) or with silver stain (Guevara et al., 1982), or they were electroblotted onto nitrocellulose membranes (BioRad) for immunological detection. In those cases where samples were used for amino acid sequence analysis, they were blotted onto PVDF membranes (Millipore). Electroblotting with a semi-dry electroblotter (JC Biotechnical Instruments) was done according to the manufacturer's instructions. Immunological detection of the membranebound proteins was done according to the method of Towbin et al. (1979) using rabbit antiserum against VWB and anti-rabbit IgG alkaline phosphatase conjugate (Sigma). Proteins electroblotted onto PVDF membranes were visualized by staining with Coomassie Blue R-250. After electroblotting the membrane was first washed with water for $5 \mathrm{~min}$ and then stained with $0.1 \%(\mathrm{w} / \mathrm{v})$ Coomassie Blue R-250 in $50 \%(\mathrm{v} / \mathrm{v})$ methanol, $10 \%(\mathrm{v} / \mathrm{v})$ acetic acid for $5 \mathrm{~min}$. Finally the membrane was washed again in water for $5 \mathrm{~min}$ and air-dried.

Separation of proteins by hydroxylapatite chromatography was carried out in the presence of SDS essentially as described by Moss \& Rosenblum (1972). After adding $0 \cdot 1$ vol. $10 \%(\mathrm{w} / \mathrm{v})$ SDS and $0.01 \mathrm{vol}$. of $\beta$-mercaptoethanol to the protein solution $\left(1 \mathrm{mg}\right.$ protein $\left.\mathrm{ml}^{-1}\right)$, the sample was boiled for $2 \mathrm{~min}$. Meanwhile, a $1 \mathrm{ml}$ column of hydrated Bio-Gel HTP hydroxylapatite (BioRad) was prepared and equilibrated with $0.01 \mathrm{M}$-sodium phosphate buffer, $\mathrm{pH} 6.4$ and $0.1 \%$ (w/v) SDS. The denatured protein sample was diluted with 20 vols column equilibrating buffer and then applied $\left(1 \mathrm{ml} \mathrm{min}^{-1}\right)$ to the hydroxylapatite column. After washing with equilibrating buffer the proteins were eluted with a linear $(0.01-0.5 \mathrm{M})$ sodium phosphate buffer $(\mathrm{pH} \mathrm{6.4)}$ gradient in $0.1 \%(\mathrm{w} / \mathrm{v})$ SDS. Flow was maintained at $1 \mathrm{ml} \mathrm{min}^{-1}$ and $2 \mathrm{~min}$ fractions were collected. The proteins in the fractions were analysed by SDS-PAGE on a $8-20 \%$ gradient gel and silver-stained.

Amino acid sequence analysis of phage proteins. Protein N-terminal amino acid sequences were determined with an automated 477A-120A protein sequencing system (Applied Biosystems). Cysteines were not alkylated and therefore not detectable.

Electrophoretically separated proteins electroblotted onto PVDF membranes were excised after staining. The excised protein bands were cut into small pieces $(2 \times 4 \mathrm{~mm})$ and placed on top of a polybreneconditioned glass fibre filter in the 477A cartridge block.

Proteins in hydroxylapatite chromatography fractions were concentrated by ultrafiltration in Ultrafree-MC filter units (Millipore) and directly applied to polybrene-conditioned glass fibre filters.

Formation and transfection of Streptomyces protoplasts. After growth of the strains for $20 \mathrm{~h}$ at $27^{\circ} \mathrm{C}, 350$ r.p.m., mycelium was harvested by centrifugation and washed in saline followed by P medium. Protoplasts 
were produced by lysozyme treatment $\left(10 \mathrm{mg} \mathrm{ml}^{-1}\right)$ at $27^{\circ} \mathrm{C}$ for $30 \mathrm{~min}$. They were then separated from mycelial remnants by centrifugation $(700 \mathrm{~g}, 5 \mathrm{~min})$ and harvested $(3000 \mathrm{~g}, 10 \mathrm{~min})$. After washing twice with $P$ medium, protoplasts were transfected using a modification of the method described by Suarez \& Chater (1980). Phage DNA $(0.5 \mu \mathrm{g}$ in $15 \mu \mathrm{l}$ TE buffer) was added to $200 \mu \mathrm{l}$ protoplast suspension $\left(\mathrm{OD}_{590}=0 \cdot 1\right)$ and immediately mixed with $500 \mu \mathrm{l} 40 \%$ (w/v) polyethylene glycol (molecular mass $6000 \mathrm{Da}$, Koch Light) dissolved in $P$ medium. This suspension was spread at different dilutions on R2YE. Transfection was assayed after $5 \mathrm{~d}$ of incubation at $27^{\circ} \mathrm{C}$. For VWB transfectants, plates were soaked with phage buffer and the presence of phages in the buffer was investigated by drop test on $S$. venezuelae $\mathrm{ETH}$ 14630. VWB04 transfectants were selected by replica plating on selective R2YE medium. Thiostrepton-resistant clones were investigated for the presence of VWB04. The procedure used gave $10^{5}-10^{6}$ transformants $\left(\mu \mathrm{g}\right.$ phage DNA) ${ }^{-1}$.

DNA manipulations and restriction enzyme digestion. Phage DNA was obtained from $\mathrm{CsCl}$-purified phages after treatment with phenol (Maniatis et al., 1982) and following dialysis $(3 \times 2 \mathrm{~h})$ against TE buffer. Chromosomal DNA of $S$. venezuelae was isolated after SDSand pronase-treatment of lysozyme-digested cells (Womble et al., 1977). E. coli plasmid DNA was obtained from cells grown in LB (300 r.p.m., $37^{\circ} \mathrm{C}, 16 \mathrm{~h}$ ) by the alkaline lysis method (Birnboim \& Doly, 1979). DNA was purified by $\mathrm{CsCl} /$ ethidium bromide gradient centrifugation (Maniatis et al., 1982). Restriction enzymes and T4 DNA ligase were supplied by Boehringer Mannheim or Pharmacia and they were used according to the manufacturer's instructions. Digested DNA was separated by electrophoresis on agarose gels using $40 \mathrm{~mm}-$ Tris/10 mM-sodium acetate/1 mM-EDTA, $\mathrm{pH} 7.8$ (Maniatis et al., 1982) as running buffer.

Oligonucleotide synthesis. Oligonucleotides were synthesized on a Gene Assembler Plus (Pharmacia). After deprotection, the oligonucleotides were desalted on an NAP-10 column and subsequently lyophilized; or, alternatively, they were purified on a Mono $Q$ ion exchanger (Pharmacia) and desalted prior to lyophilization.

Southern blotting and DNA labelling reactions. After separation of DNA restriction fragments by agarose gel electrophoresis the DNA was blotted onto Hybond-N membranes (Amersham) according to the manufacturer's instructions. Blotting was obtained either through capillary action (Southern, 1975) or using a Vacugene system (Pharmacia). The DNA of interest bound to the membrane was detected by hybridization. When VWB DNA was used as probe, it was labelled with $\left[\alpha^{-32} \mathrm{P}\right] \mathrm{dCTP}\left(3000 \mathrm{Ci} \mathrm{mmol}^{-1}=111 \mathrm{TBq} \mathrm{mmol}^{-1}\right)$ by the method of random primed labelling (Feinberg \& Vogelstein, 1983) applying the DNA labelling kit supplied by Boehringer Mannheim or using Boehringer Mannheim's non-radioactive DNA labelling and detection kit. When applicable, hybridization was done with $1-5 \times 10^{4}$ c.p.m. $\mathrm{cm}^{-2}$ at $65^{\circ} \mathrm{C}$ overnight and washing was done under stringent conditions according to the manufacturer's instructions for Hybond-N. Oligonucleotides used as DNA probe were end-labelled as follows. Oligonucleotides $(2-4 \mathrm{nmol})$ were dissolved in $40 \mu \mathrm{l}$ water and mixed with $5 \mu \mathrm{l}$ kinase buffer (700 mM-Tris/ $\mathrm{HCl}, \mathrm{pH} 7 \cdot 6,100 \mathrm{~mm}-\mathrm{MgCl}_{2}, 50$

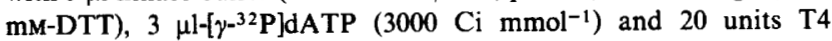
polynucleotide kinase. The reaction was carried out at $37^{\circ} \mathrm{C}$ for $30 \mathrm{~min}$. The oligonucleotides were next precipitated by adding 0.1 vol. sodium acetate ( $3 \mathrm{~m}, \mathrm{pH} 6.0), 20 \mu \mathrm{g}$ tRNA and 1 vol. of propan-2-ol. After $30 \mathrm{~min}$ at $-70^{\circ} \mathrm{C}$, the precipitated DNA was centrifuged in an Eppendorf centrifuge. The DNA pellet was dried in a vacuum rotor (Speed Vac Concentrator) and redissolved in $200 \mu \mathrm{l}$ TE. Hybridization was done with about $1-5 \times 10^{4}$ c.p.m. $\mathrm{cm}^{-2}$ at $65^{\circ} \mathrm{C}$ overnight. Washing was under non-stringent conditions (twice with $2 \times \mathrm{SSC}$ at $\left.65^{\circ} \mathrm{C}\right)(1 \times \mathrm{SSC}$ is $0 \cdot 15 \mathrm{M}-\mathrm{NaCl}, 0 \cdot 015 \mathrm{M}$-trisodium citrate, $\mathrm{pH} 7 \cdot 0)$.
Both hybridization and washing were as described in the protocol for Hybond-N.

\section{Results and Discussion}

\section{Adsorption and growth characteristics of phage $V W B$}

Adsorption of VWB was determined using $S$. venezuelae ETH 14630 cells grown in phage medium to the early exponential growth phase, i.e. $15 \mathrm{~h}$ cultures. Most phages quickly adsorbed to the cells. About $70 \%$ of all infective VWB particles were adsorbed within $20 \mathrm{~min}$ after contact. The adsorption constant $(=K)$ was $0.6 \times 10^{-8}$ $\mathrm{ml} \mathrm{min}^{-1}$ as determined by the formula $K=2 \cdot 3 /(B) t \times$ $\log \left(p_{0} / p\right)$ (Adams, 1959), where $p_{0}=$ phage assay at zero time, $p=$ phage not adsorbed at time $t \min ,(B)=$ concentration of bacteria as number of cells $\mathrm{ml}^{-1}$ and $K=$ velocity constant expressed as $\mathrm{ml} \mathrm{min}^{-1}$.

One-step growth experiments indicated that VWB has a latent period of $140 \mathrm{~min}$, followed by a rise period of $100 \mathrm{~min}$ (Fig. 1). Although the length of these periods is not exceptional, they are rather long compared to those of many other actinophages (Lomovskaya et al., 1980). The mean burst size was estimated to be $130-250$ p.f.u.

\section{Host-range determination of $V W B$ to different $S$. venezuelae strains}

It has previously been observed that VWB has a very narrow host range (Anné et al., 1984). Further investigations on the host range versus different $S$. venezuelae strains showed that VWB infects $S$. venezuelae ETH 14630 but no other $S$. venezuelae strain (Table 1). This observation raised the question about the ETH 14630 strain being $S$. venezuelae. Reinvestigation of the culture by numerical cluster analysis indicated that the ETH 14630 strain resembles the $S$. venezuelae type strain ATCC 10712 (W. Wohlleben, personal communication), but it also shows a close relationship to $S$. exfoliatus ATCC 12672. Moreover, $S$. exfoliatus could be infected by VWB and when comparing the host range of three other $S$. venezuelae phages, $S$. venezuelae ETH 14630 and $S$. exfoliatus indeed showed a close relationship (Table 1).

In order to explain the narrow host range of VWB we also investigated the adsorption of this phage to other $S$. venezuelae strains. From these experiments it could be concluded that under the test conditions VWB efficiently adsorbed to ETH 14630 and to $S$. exfoliatus, but not to any of the other $S$. venezuelae strains tested (data not shown). Adsorption was, therefore, one of the restricting factors. The limited adsorption (1-10\%) of VWB to the different $S$. venezuelae strains could be due to non- 


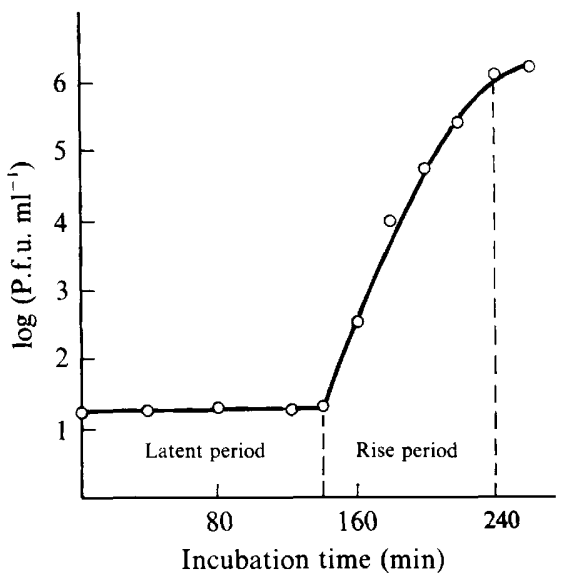

Fig. 1. One-step growth curve of phage VWB development on S. venezuelae ETH 14630. specific adsorption phenomena. Efficient adsorption (more than $90 \%$ under the test conditions) of VWB to $S$. venezuelae ETH 14630 and to $S$. exfoliatus was probably due to particular phage receptor proteins at the cell surface of these strains. However, VWB or its derivative VWB04 could be introduced in most $S$. venezuelae strains by transfection (Table 1). Moreover, they could also lysogenize these strains, as observed with VWB04. In this case the phage DNA became inserted in the host chromosome, rendering the strain thiostreptonresistant. From these lysogens free phage particles could be isolated. After multiplication on ETH 14630 analysis of their DNA proved that the phage particles consisted of VWB04. It is evident that no plaques could be observed on $S$. venezuelae strains different from ETH 14630 when transfected with VWB DNA, because these phages could not infect the surrounding cells.
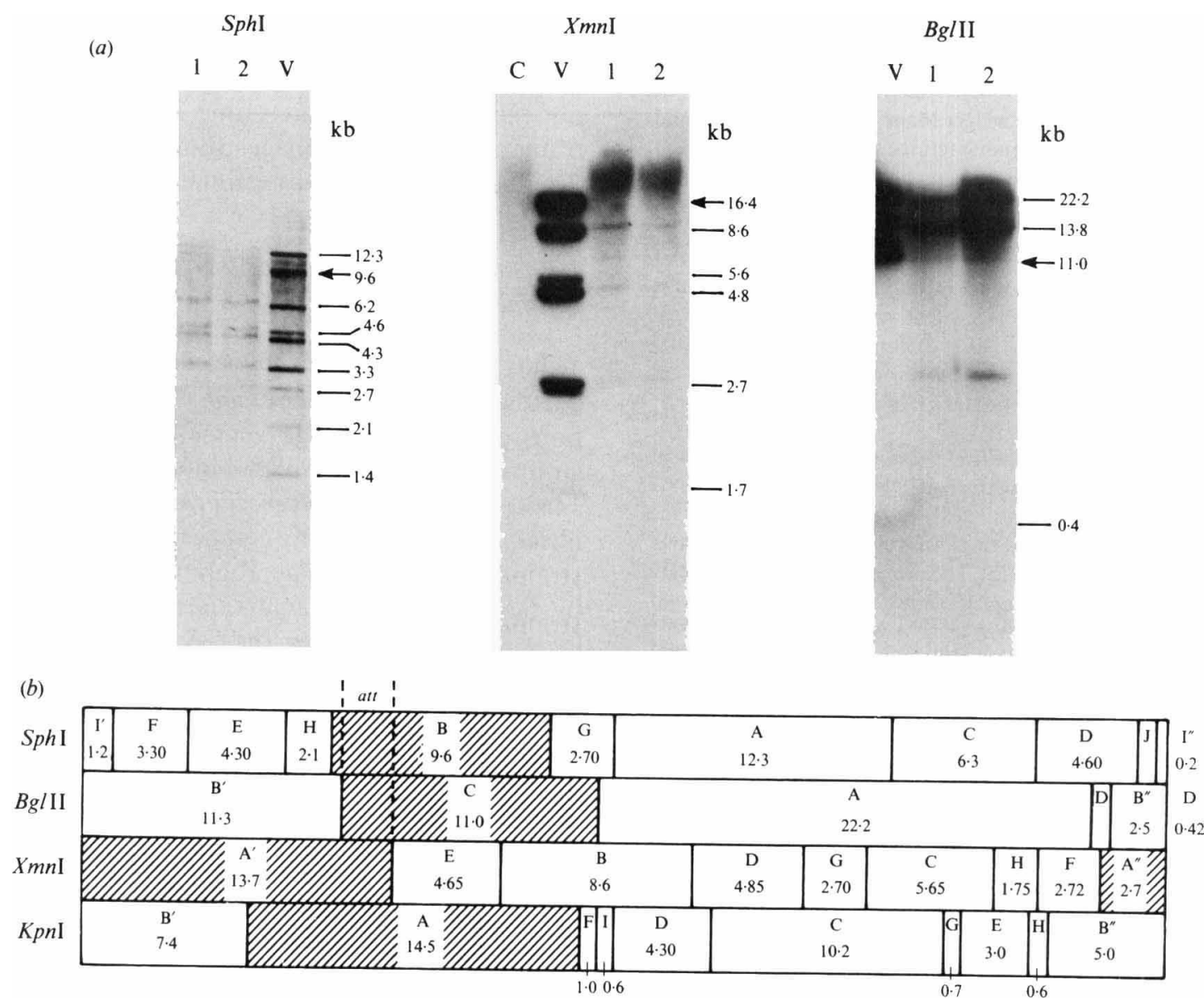

Fig. 2. (a) Mapping of prophage VWB DNA by comparison between restriction endonuclease digests of phage VWB and of chromosomal DNA isolated from $S$. venezuelae ETH 14630 lysogenized with VWB. Mapping was done using Southern blots following hybridization with VWB DNA labelled either with digoxigenin (SphI digest) or radioactively labelled ( $X m n I$ and $B g l \mathrm{II}$ digests). Identification of restriction fragments containing the att site was achieved by scoring the bands with changed mobility (arrowed). The size of the original bands are indicated. Lanes 1 and 2, chromosomal DNA of lysogens; V, VWB; C, control $S$. venezuelae chromosomal DNA. (b) Restriction map of phage VWB showing the fragments that contain the att site (שAA). In this manner the att site was localized on a $2.5 \mathrm{~kb} B g l \mathrm{II}-X m n I$ fragment. 
Table 1. Host range of several S. venezuelae phages on different $S$. venezuelae strains and on $S$. exfoliatus

\begin{tabular}{|c|c|c|c|c|c|c|}
\hline \multirow[b]{2}{*}{ Host } & \multicolumn{4}{|c|}{ After infection } & \multicolumn{2}{|c|}{$\begin{array}{c}\text { After } \\
\text { transfection }\end{array}$} \\
\hline & VWB & SV1 & SVL1 & VW3 & VWB & VWB04 \\
\hline S. venezuelae ETH 14630 & + & + & - & + & + & + \\
\hline S. venezuelae ATCC 10595 & - & + & + & + & + & + \\
\hline S. venezuelae ATCC 10712 & - & + & - & + & + & + \\
\hline S. venezuelae ATCC 14583 & - & - & - & - & - & - \\
\hline S. venezuelae ATCC 21113 & - & - & - & - & + & + \\
\hline S. venezuelae DSM 40727 & - & - & - & - & $-*$ & $-*$ \\
\hline S. exfoliatus ATCC 12672 & + & + & - & + & + & + \\
\hline
\end{tabular}

* No protoplasts obtained.

During the determination of the VWB host range to other $S$. venezuelae strains it was noticed that the type strain ATCC 10712 is a lysogenic strain. In the supernatant of liquid cultures or after soaking plates containing mycelia of strain ATCC 10712, a phage could be detected that produced clear plaques on ATCC 10595 (Table 1). This phage, designated SVL1, was spontaneously released from ATCC 10712. Since the latter strain is a lysogen, it could not be infected by this phage probably as a result of phage homoimmune superinfection. The observation of the ATCC 10712 strain harbouring an actinophage was independently observed by Hahn et al. (1988). The occurrence of wild-type actinomycetes being lysogens is not totally unusual. It has been described earlier, e.g. for Streptomyces hygroscopicus (Rautenstein et al., 1976), Streptomyces rimosus (Hranueli et al., 1979), Streptomyces lividans 803 (Lomovskaya et al., 1980), Streptomyces galilaeus (Kuhn et al., 1987) and Faenia rectivirgula (Schneider et al., 1987).

\section{Localization of the att site on the VWB phage genome}

In order to locate the att site on the phage genome, we isolated chromosomal DNA from several lysogens of $S$. venezuelae ETH 14630 , digested it with restriction endonucleases and compared the restriction pattern to those of ligated VWB DNA. After digestion and electrophoresis the restriction fragments were blotted onto a membrane by Southern blotting and visualized by probing with ${ }^{32} \mathrm{P}$-labelled or digoxigenin-labelled VWB DNA. The restriction bands containing the att site could be detected because in the DNA of the lysogens this restriction band is lost as a result of the addition of bacterial chromosomal DNA at the att site. Instead, two new bands representing the right and left phage DNAbacterial DNA junction bands appear.

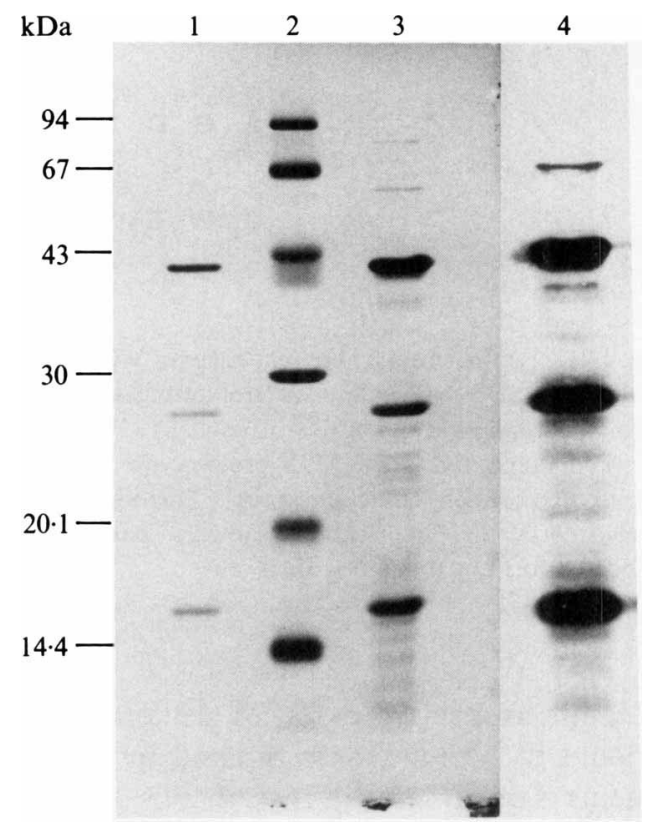

Fig. 3. SDS-PAGE of phage VWB proteins on a $12.5 \%$ gel. The amount of proteins applied per sample was $10 \mu \mathrm{g}$ (lane 1) and $40 \mu \mathrm{g}$ (lane 3). Proteins were visualized by Coomassie staining. Lane 4 contained $2.5 \mu \mathrm{g}$ phage proteins made visible following immunoblotting using an anti-rabbit IgG alkaline phosphatase conjugate. The calibration kit (Pharmacia) used for molecular mass determinations (lane 2) consisted of phosphorylase $b(94 \mathrm{kDa})$, albumin $(67 \mathrm{kDa})$, ovalbumin $(43 \mathrm{kDa})$, carbonic anhydrase $(30 \mathrm{kDa})$, trypsin inhibitor $20 \cdot 1 \mathrm{kDa})$ and $\alpha$-lactalbumin $(14 \cdot 4 \mathrm{kDa})$.

In this manner the att site could be located on a $2.5 \mathrm{~kb}$ $B g l \mathrm{II}-X m n I$ restriction fragment (Fig. $2 b$ ). The fragments $S p h \mathrm{I} / \mathrm{B}, B g l \mathrm{II} / \mathrm{C}, K p n \mathrm{I} / \mathrm{A}$ (data not shown) and $X m n I / A$ disappeared and new bands became visible (Fig. 2a). Since it was observed that in different lysogens the same restriction fragments always contained the att site and the newly formed bands were always identical, it could be concluded that the phage usually integrated into a preferred site.

\section{Protein composition of $V W B$}

Electron microscopic investigations of VWB have shown that this phage has an icosahedral head, a long tail and a base-plate like structure (Anné et al., 1984). Electrophoresis of $\mathrm{CsCl}$ gradient-purified phage particles on 12.5 or $15 \%$ SDS-PAGE revealed the presence of at least 17 protein bands, a similarly high number of protein bands as observed with $\phi C 31$ (Suarez et al., 1984). Molecular masses ranged between 12 and $83 \mathrm{kDa}$ (Fig. 3). Coomassie and immunoblotting staining clearly showed that three bands with molecular masses of $16.5 \mathrm{kDa}$, $27.2 \mathrm{kDa}$ and $43 \mathrm{kDa}$ are the most prominent proteins. 


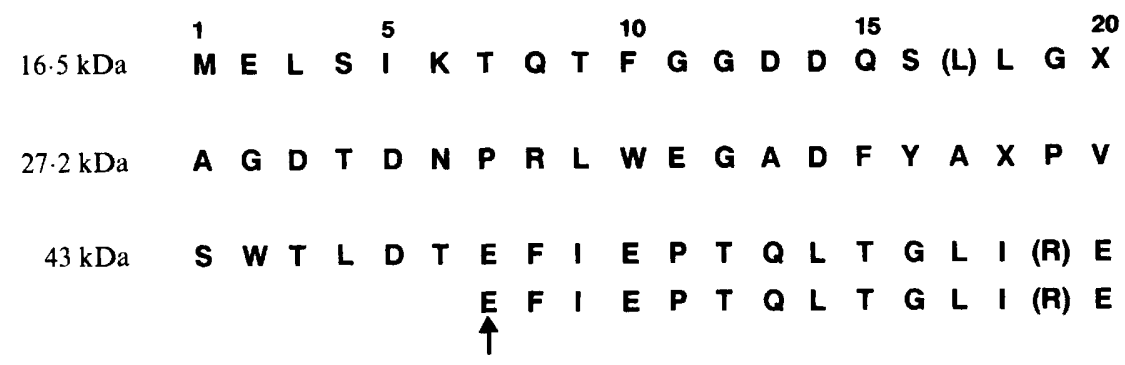

Fig. 4. N-terminal amino acid sequences of VWB proteins. The sequence of the $16.5 \mathrm{kDa}$ protein was determined using both material purified by SDS-PAGE and electroblotting to PVDF ( $85 \mathrm{pmol}$, repetitive yield $87 \%$ ) and material purified by hydroxylapatite chromatography $(40 \mathrm{pmol}$, repetitive yield $83 \%)$; the sequences of the $27.2 \mathrm{kDa}(141 \mathrm{pmol}$, repetitive yield $88 \%)$ and the $43 \mathrm{kDa}$ (67 pmol, repetitive yield $90 \%$ ) proteins were derived from hydroxylapatite-chromatography-purified material. Amino acids are represented by their one-letter symbols. Positions where no amino acids could be identified are indicated by an X. Amino acids that are likely to occur in a sequence are shown in parentheses. The arrow in the $43 \mathrm{kDa}$ protein sequence indicates the $\mathrm{N}$-terminus of the truncated form of this molecule.

They account, respectively, for 24,10 and $20 \%$ of the total amount of proteins as estimated by Gelscan XL (Pharmacia). The proteins in these bands are thought to be capsid proteins. In most bacteriophage proteins analysed by SDS-PAGE, three to four structural proteins are similarly present in much higher amounts than the other proteins (Murialdo \& Siminovitch, 1971; Relano et al., 1987; Suarez et al., 1984; Trautwetter et al., 1987). In all instances these major proteins are proven or thought to be major head and tail proteins. Some minor bands could be contaminating host proteins or precursor polypeptides of the phage structural proteins that have been incorporated into the capsids or remained absorbed to the phage particles.

\section{$N$-terminal amino acid sequence analysis of $V W B$ proteins}

In a first approach $40 \mu \mathrm{g}$ VWB proteins were separated by SDS-PAGE and electroblotted onto a PVDF membrane. After staining, the three major protein bands $(16.5,27.2$ and $43 \mathrm{kDa})$ were excised from the PVDF membrane and subjected to 20 Edman degradation cycles. Of the $16.5 \mathrm{kDa}$ protein 18 amino acids could be identified (Fig. 4). In contrast, no sequence could be obtained for the 27.2 and $43 \mathrm{kDa}$ proteins due to insufficient sequenceable material.

To prepare sufficient amounts of purified proteins for sequencing, $500 \mu \mathrm{g}$ of a VWB protein preparation was subjected to hydroxylapatite chromatography. Fractions containing only one protein were concentrated and sequenced. The sequence obtained for the $16.5 \mathrm{kDa}$ protein was identical to the sequence obtained after SDSPAGE and electroblotting. In addition, the amino acid at position 17 was likely to be a leucine residue. The $20 \mathrm{~N}$-terminal amino acids of the $27.2 \mathrm{kDa}$ protein (with the exception of residue 18 ) and of the $43 \mathrm{kDa}$ protein were also determined from material recovered from hydroxylapatite chromatography. Remarkably, the $43 \mathrm{kDa}$ protein showed $\mathrm{N}$-terminal heterogeneity, since about $19 \%$ of the molecules started with $\mathrm{Glu}_{7}$. This explains the observation that a protein with a slightly lower molecular mass co-purified with the $43 \mathrm{kDa}$ protein during hydroxylapatite chromatography (data not shown).

\section{Localization of the three most prominent structural proteins on the phage genome}

Certain bacteriophages, e.g. $\lambda$ (Hendrix et al., 1983), T7 (Hausmann, 1976), P1 (Sternberg \& Hoess, 1983) have a well-characterized genetic map. These maps were constructed by painstaking genetic work using numerous different mutants. From these maps it became clear that the genes coding for the structural proteins are clustered. With respect to actinophages, a relatively detailed genetic map is available for only one phage, $\phi \mathrm{C} 31$ (Lomovskaya et al., 1980).

In order to study the genetic organization of VWB, we intended to map the three most prominent structural proteins by probing with mixtures of synthetic oligonucleotides based on the results of $\mathrm{N}$-terminal amino acid sequencing, instead of using classical genetic means. The choice of oligonucleotides to be synthesized was based on the observation that the codon usage in Streptomyces shows a marked asymmetry in favour of codons with $\mathrm{G}$ or $\mathrm{C}$ in the third position (Hopwood et al., 1986). To minimize the number of possible oligonucleotides corresponding to the $\mathrm{N}$-terminal amino acids of the prominent structural proteins the following amino acids were chosen for the different proteins: $16.5 \mathrm{kDa}=$ QTFGGDDQ; $27.2 \mathrm{kDa}=$ WEGADFYA and $43 \mathrm{kDa}$ $=$ EFIEPTQL. Taking into account the average codon usage in Streptomyces the oligonucleotide mixtures contained a total of 18 different $24-$ mers in the case of the 


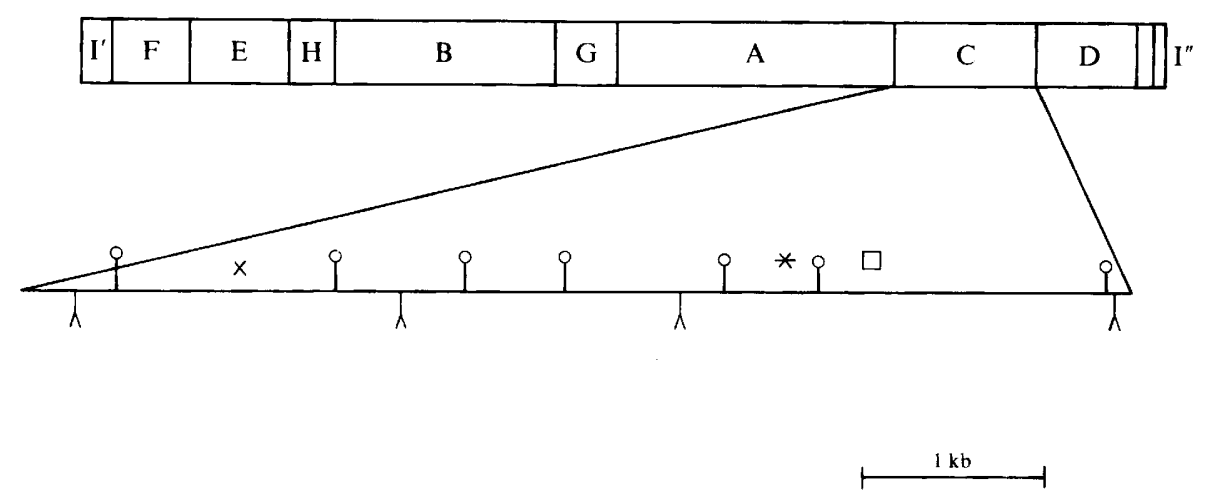

Fig. 5. Localization on the restriction map of VWB of the DNA region coding for the N-terminal amino acid sequence of the 16.5 ( $\square$ ), $27 \cdot 2(\mathrm{X})$ and $43(*) \mathrm{kDa}$ proteins. Localization was done by hybridization of restriction fragments of VWB on Southern blots using as probe mixtures of oligonucleotides synthesized on the basis of the known $\mathrm{N}$-terminal amino acid sequences. The upper open bar shows the restriction map of VWB digested with $S p h I$. The other line represents the $S p h \mathrm{I} / \mathrm{C}$ fragment $(6 \cdot 2 \mathrm{~kb})$ and $A p a \mathrm{I}(\lambda)$ and $P v u I I(P)$ restriction sites.

16.5 $\mathrm{kDa}$ protein, and 12 and 32 different 23 -mers for the $27 \cdot 2 \mathrm{kDa}$ and $43 \mathrm{kDa}$ proteins, respectively.

The mixtures were end-labelled and hybridized to different restriction fragments of VWB DNA separated on agarose gels. By this method, it was observed that the start sites of the coding regions of the prominent proteins were all located in the $S p h \mathrm{I} / \mathrm{C}$ fragment $(6.2 \mathrm{~kb})$ (Anné $e t$ al., 1985). Finer mapping obtained after cloning the SphI/C fragment in pBR322 followed by restriction enzyme analysis of the cloned fragment indicated that the $16.5 \mathrm{kDa}$ and $43 \mathrm{kDa}$ proteins are located very close to each other (Fig. 5).

From these results it could be concluded that in VWB the genes coding for the main structural proteins are clustered in the same way as in bacteriophages investigated, e.g. $\lambda, T 4$ and T7. Sequencing of the genes coding for the prominent structural proteins is in progress. Comparison of these sequences to those of other bacteriophages is without doubt of much interest for evolutionary studies.

\section{References}

Ackermann, H.-W., Berthiaume, L. \& Jones, L. A. (1985). New actinophage species. Intervirology 23, 121-130.

ADAMS, M. H. (1959). Bacteriophages. New York: Interscience.

ANNÉ, J., Wohlleben, W., Burkardt, H. J., SPRINGER, R. \& PÜHLER, A. (1984). Morphological and molecular characterization of several actinophages isolated from soil which lyse Streptomyces cattleya or S. venezuelae. Journal of General Microbiology 130, 2639-2649.

ANné, J., Verheyen, P., VolCKaert, G. \& Eyssen, H. (1985). A restriction endonuclease map of Streptomyces phage VWB. Molecular and General Genetics 200, 506-507.

BiRnboim, H. C. \& Doly, J. (1979). A rapid alkaline extraction procedure for screening recombinant plasmid DNA. Nucleic Acids Research 7, 1513-1522.
Bolivar, F., Rodriguez, R., Green, P. J., Betlach, M., Heyneker, H. L., Boyer, H. W., Crosa, J. \& FalKow, S. (1977). Construction and characterization of new cloning vehicles. II. A multipurpose cloning system. Gene 2, 95-113.

CHATER, K. F. (1986). Streptomyces phages and their application to Streptomyces genetics. In The Bacteria, vol. 9, Antibiotic-producing Streptomyces, pp. 119-158. Edited by S. W. Queener \& L. E. Day. Orlando, Florida: Academic Press.

Chung, S.-T. \& Thompson, S. A. (1985). Physical and genetic characterization of actinophage SF1, a P1-like phage isolated from Streptomyces fradiae. In Microbiology - 1985, pp. 431-435. Edited by L. Leive \& D. Schlessinger. Washington, DC: American Society for Microbiology.

Chrambach, A., Reisfeld, R. A., Wyckoff, M. \& ZaCCARI, J. (1967). A procedure for rapid and sensitive staining of protein fractionated by polyacrylamide gel electrophoresis. Analytical Biochemistry 20, 150-154.

Feinberg, A: P. \& Vogelstein, B. (1983). A technique for radiolabelling DNA restriction endonuclease fragments to high specific activity. Analytical Biochemistry 132, 6-13.

Guevara, J. JR, Johnston, D. A., Ramagali, L. S., Martin, B. A., CAPETILLO, S. \& Rodriguez, L. V. (1982). Quantitative aspects of silver deposition in proteins resolved in complex polyacrylamide gels. Electrophoresis 3, 197-205.

HAHN, K., StutTARD, C. \& Allen, S. (1988). Streptomyces venezuelae ISP5230 is a non-defective cryptic lysogen. In Abstract Book of the 4th ASM Conference on the Genetics and Molecular Biology of Industrial Microorganisms, p. 30. Washington DC: American Society for Microbiology.

HausmanN, R. (1976). Bacteriophage T7 genetics. Current Topics in Microbiology and Immunology 75, 77-110.

Hendrix, R. W., Roberts, J. W., Stahl, F. W. \& Weisberg, R. A. (1983). Lambda II. Cold Spring Harbor, NY: Cold Spring Harbor Laboratory.

Hopwood, D. A., BibB, M. J., Chater, K. F., Kieser, T., Bruton, C. J., KIESER, H. M., LydiATE, D. J., SMITH, C. P., WARD, J. M. \& SCHREMPF, H. (1985). Genetic Manipulation of Streptomyces - a Laboratory Manual. Norwich: John Innes Foundation.

Hopwood, D. A., Bibb, M. J., Chater, K. F., Janssen, G. R., Malpartida, F. \& SMITH, C. P. (1986). Regulation of gene expression in antibiotic producing Streptomyces. In Regulation of Gene Expression - 25 years on, pp. 251-276. Edited by I. R. Booth \& C. F. Higgins. Cambridge: Cambridge University Press.

Hranueli, D., PigaC, J. \& VeŠligaj, M. (1979). Characterization and persistence of actinophage RP2 isolated from Streptomyces rimosus ATCC 10970. Journal of General Microbiology 114, 295-303. 
KuHN, S. P., Lampel, J. S. \& STrohl, W. R. (1987). Isolation and characterization of a temperate bacteriophage from Streptomyces galilaeus. Applied and Environmental Microbiology 53, 2708-2713.

LAEMMLI, U. K. (1970). Cleavage of structural proteins during the assembly of the head of bacteriophage T4. Nature, London 227, $680-685$.

Lomovskaya, N. D., Chater, K. F. \& Mkrtumian, N. M. (1980). Genetics and molecular biology of Streptomyces phages. Microbiological Reviews 44, 206-229.

Maniatis, T., Fritsch, E. F. \& Sambrook, J. (1982). Molecular Cloning: a Laboratory Manual. Cold Spring Harbor, NY: Cold Spring Harbor Laboratory.

MCHenney, M. A. \& Baltz, R. H. (1988). Transduction of plasmid DNA in Streptomyces spp. and related genera by bacteriophage FP43. Journal of Bacteriology 170, 2276-2282.

Miller, J. H. (1972). Experiments in Molecular Genetics. Cold Spring Harbor, NY: Cold Spring Harbor Laboratory.

Moss, B. \& RosenBlum, E. N. (1972). Hydroxylapatite chromatography of protein-sodium dodecyl sulfate complexes. Journal of Biological Chemistry 247, 5194-5198.

MuRIALDO, H. \& Siminovirch, L. (1971). The morphogenesis of bacteriophage lambda III. Identification of genes specifying morphogenetic proteins. In Bacteriophage Lambda, pp. 711-723. Edited by A. D. Hershey. Cold Spring Harbor, NY: Cold Spring Harbor Laboratory.

OKANISHI, M., SUZUKI, K. \& UMEZAWA, H. (1974). Formation and reversion of streptomycete protoplasts: cultural conditions and morphological study. Journal of General Microbiology 81, 389-400.

Rautenstein, Y. I., SOloveva, N. Y., Roth, M., NoaCK, D. \& KLAUS, S. (1976). Lysogeny of a strain of Streptomyces hygroscopicus producing turimycin and some features of its temperate phage. Mikrobiologiya 45, 922-925.

Relano, P., Mata, M., Bonneau, M. \& Ritzenthaler, P. (1987). Molecular characterization and comparison of 38 virulent and temperate bacteriophages of Streptococcus lactis. Journal of General Microbiology 133, 3053-3063.
Schneider, J., Aguilera Garcia, I. \& Kutzner, H. J. (1987). Characterization of a family of temperate actinophages of Faenia rectivirgula. Journal of General Microbiology 133, 2263-2268.

SinClaIR, R. B. \& BiBB, M. J. (1988). The repressor gene (c) of the Streptomyces temperate phage of $\phi \mathrm{C} 31$ : nucleotide sequence, analysis and functional cloning. Molecular and General Genetics 213, 269-277.

SOUTHERN, E. M. (1975). Detection of specific sequences among DNA fragments separated by gel electrophoresis. Journal of Molecular Biology 98, 503-517.

SteRnBerG, N. \& HoEss, R. (1983). The molecular genetics of bacteriophage P1. Annual Review of Genetics 17, 123-154.

StUTTARD, C. (1983). Localized hydroxylamine mutagenesis and cotransduction of threonine and lysine genes in Streptomyces venezuelae. Journal of Bacteriology 155, 1219-1223.

SuARez, J. E. \& Chater, K. F. (1980). Polyethylene glycol-assisted transfection of Streptomyces protoplasts. Journal of Bacteriology 142, 8-14.

Suarez, J. E., Caso, J. L., Rodriguez, A. \& Hardisson, C. (1984). Structural characteristics of the Streptomyces bacteriophage $\phi \mathrm{C} 31$. FEMS Microbiology Letters 22, 113-117.

Towbin, H., Staehelin, T. \& GoRDON, J. (1979). Electrophoretic transfer of proteins from polyacrylamide gels to nitrocellulose sheets : procedure and some applications. Proceedings of the National Academy of Sciences of the United States of America 76, 4350-4354.

Trautwetter, A., Blanco, C. \& Bonnassie, S. (1987). Characterization of the corynebacteriophage CG33. Journal of General Microbiology 133, 2945-2952.

Van Mellaert, L., ANNÉ, J. \& Eyssen, H. (1987). Development of a phage-based cloning system for Streptomyces venezuelae. Mededelingen van de Faculteit Landbouwwetenschappen, Rijksuniversiteit Gent 52, 1847-1852.

WOMBLE, D. D., TAYLOR, D. P. \& RowaRD, R. M. (1977). Method for obtaining more-accurate covalently closed circular plasmid to chromosome ratio from bacterial lysates by dye-buoyant density centrifugation. Journal of Bacteriology 130, 148-153. 